\title{
TANGGUNG GUGAT RUMAH SAKIT ATAS KESALAHAN DIAGNOSA YANG DILAKUKAN OLEH DOKTER
}

\author{
Hikmah Yuli Octavia \\ Fakultas Hukum, Universitas Airlangga \\ hikmahyulioctavia@gmail.com \\ Aulia Yohana \\ Fakultas Hukum, Universitas Airlangga \\ Nur Atika Ramadhani \\ Fakultas Hukum, Universitas Airlangga
}

\begin{abstract}
Abstrak
Tujuan dari penulisan paper ini adalah untuk dapat mengetahui Apakah rumah sakit bertanggung gugat atas kesalahan diagnosa dokter. Penelitian ini merupakan penelitian hukum normatif dengan menggunakan metode pendekatan perundang-undangan dan pendekatan konseptual. Tindakan dokter yang tidak sesuai dengan standar profesi dapat dikulifikasikan sebagai perbuatan melanggar hukum. Atas tindakan dokter yang dilakukan tidak sesuai prosedur maka pasien berhak untuk meminta ganti rugi. Perbuatan melanggar hukum yang dilakukan oleh dokter yang bekerja pada rumah sakit melahirkan tanggung gugat resiko (risico aanspraklijkheid) pada rumah sakit.
\end{abstract}

Kata Kunci: Tanggung Gugat, Rumah Sakit, Kesalahan Diagnosa

\section{Abstract}

The purpose of writing this paper is to be able to find out whether the hospital is responsible for the doctor's misdiagnosis. This research is a normative legal research using the legislation approach and conceptual approach. Doctors who do not comply with professional standards can be classified as unlawful acts. For the actions of the doctor performed not according to the procedure, the patient has the right to ask for compensation. Unlawful acts carried out by doctors who work in hospitals give birth to risk liability (risico aanspraklijkheid) at hospitals.

Keywords: Liability, Hospital, Error Diagnosis

\section{Pendahuluan}

Kesehatan merupakan hal yang sangat penting bagi semua manusia, karena tanpa kesehatan yang baik setiap manusia akan sulit dalam melaksanakan aktivitasnya sehari-hari. Setiap orang berhak atas kesehatan, hak tersebut merupakan suatu tanggungjawab yang diemban oleh negara dan harus diberikan pemenuhannya berupa fasilitas pelayanan kesehatan bagi setiap warga masyarakat tanpa terkecuali. Hal ini sebagaimana diatur di dalam Pasal 1 angka 7 Undang-Undang Nomor 36 Tahun 2009 tentang Kesehatan (UU No. 36 Th. 2009), bahwa "yang dimaksud dengan 
fasilitas pelayanan kesehatan adalah suatu alat dan/atau tempat yang digunakan untuk menyelenggarakan upaya pelayanan kesehatan, baik promotif, preventif, kuratif maupun rehabilitatif yang dilakukan oleh Pemerintah, pemerintah daerah, dan/atau masyarakat". Pelayanan

membutuhkan

kesehatan tempat penyelenggaraan kesehatan salah satu di antaranya, yaitu rumah sakit adalah institusi pelayanan kesehatan bagi masyarakat dengan karateristik tersendiri yang dipengaruhi oleh perkembangan ilmu pengetahuan kesehatan, kemajuan teknologi, dan kehidupan sosial ekonomi masyarakat yang harus tetap mampu meningkatkan pelayanan yang lebih bermutu dan terjangkau oleh masyarakat agar terwujud derajat kesehatan yang setinggitingginya, sebagaimana konsideran Undang-Undang Nomor 44 Tahun 2009 tentang Rumah Sakit (No. 44 Th. 2009).

Rumah sakit dilengkapi dengan tenaga kesehatan, tenaga kesehatan menurut Pasal 1 angka 1 Undang-Undang Nomor 36 Tahun 2014 tentang Tenaga Kesehatan (UU No. 36 Th. 2014) adalah "setiap orang yang mengabdikan diri dalam bidang kesehatan serta memiliki pengetahuan dan/atau keterampilan melalui pendidikan di bidang kesehatan yang untuk jenis tertentu memerlukan kewenangan untuk melakukan upaya kesehatan".

Di antara tenaga kesehatan dibedakan antara tenaga medis dan tenaga non medis. Tenaga medis terdiri atas dokter, dokter gigi, dokter spesialis, dan dokter gigi spesialis. Tenaga non medis merupakan karyawan rumah sakit yang mengurusi hal-hal administrasi dan operasional rumah sakit seperti staf administrasi, staf keuangan, tenaga kebersihan, tenaga keamanan dan lain sebagainya.

Dokter dalam menjalankan profesinya memperoleh perlindungan hukum sebagaimana Pasal 50 Undang-Undang Nomor 29 Tahun 2004 tentang Praktik Kedokteran (selanjutnya disingkat UU No. 29 Th. 2004) yang menentukan: Dokter dalam melaksanakan praktik kedokteran mempunyai hak: a) memperoleh perlindungan hukum sepanjang melaksanakan tugas sesuai dengan standar profesi dan standar prosedur operasional; b) memberikan pelayanan medis menurut standar profesi dan standar prosedur operasional; c) memperoleh informasi yang lengkap dan jujur dari pasien atau keluarganya; dan d) menerima imbalan jasa.

Mengenai standar profesi dijelaskan lebih lanjut pada Penjelasan Pasal 50 UU No. 29 Th. 2004, bahwa "standar profesi adalah batasan kemampuan (knowledge, skill, and professional attitude) minimal harus dikuasai oleh seorang individu untuk dapat melakukan kegiatan profesionalnya pada masyarakat secara mandiri yang dibuat oleh organisasi profesi".

Hubungan yang terjadi antara Dokter dengan Pasien lazim dikenal dengan nama Transkaksi Teraupetik. Transaksi terapeutik adalah "suatu transaksi untuk menentukan atau upaya mencari terapi yang paling tepat bagi pasien yang dilakukan oleh dokter". (Nasution, 2013) Ada dua unsur yang menentukan proses 
pemeliharaan atas perbuatan yang lahir sebagai akibat dari terjadinya transaksi terapeutik, yaitu pertama, Unsur yang terdapat di dalam diri dokter yang berdasarkan itikad baik untuk memilih tindakan terapeutik yang paling tepat dalam usahanya untuk menyembuhkan pasien dan kedua, unsur yang ada dalam diri pasien yang dibekali niat itikad baik sesuai dengan norma-norma yang hidup di dalam masyarakat dengan cara memberikan informasi yang cukup untuk dapat dipakai sebagai bahan pertimbangan bersama-sama dengan dokter dalam memutuskan langkah yang terbaik untuk penyembuhannya. (Koeswadji, 2002)

Pada hubungan yang terjadi antara Dokter dengan Pasien seringkali terjadi permasalahan yang membawa Dokter kepada gugatan baik pidana maupun perdata. Dalam proses perdata yang menyangkut gugatan seorang pasien terhadap dokter yang menanganinya, hampir semua kalau tidak dapat dikatakan semuanya, adalah menyangkut masalah tuntutan ganti rugi. Permasalahan yang terjadi antara Dokter dengan Pasien salah satunya terjadi dalam kasus berikut: Salah seorang anggota keluarga pasien merasa kecewa dengan dokter rumah sakit $X$ karena salah mendiagnosa penyakit anggota keluarganya. Permasalahan terjadi ketika itu Oktober 2015, seorang ibu berinisial $S$ mengeluhkan sakit di bagian perut, karena sakit tidak kunjung reda maka keluarga memeriksakan $S$ ke rumah sakit $X$ dan ditangani oleh dua dokter spesialis obstetri dan ginekologi. Pada hasil pemeriksaan, dokter mendiagnosa kalau $S$ mengidap kista, oleh dokter disarankan untuk melakukan operasi. Saran dokter disetujui oleh pihak keluarga dan operasi dilaksanakan pada tanggal 27 Oktober 2015, namun saat operasi berlangsung penyakit yang diderita oleh $S$ ternyata bukan kista, melainkan penyempitan saluran kencing.

Setelah dioperasi, menurut E anak kandung $S$, kondisi ibunya mulai membaik, namun pada tanggal 3 Nopember 2015, kondisinya malah menurun sehingga $S$ kembali dibawa ke Rumah Sakit X oleh pihak keluarga. Saat itu dokter langsung melakukan penanganan dan akhirnya diperbolehkan pulang. Namun, S diminta untuk kembali kontrol ke poliklinik kandungan, dokter langsung melakukan pemeriksaan dan menyatakan kondisi pasien cukup baik, tiba-tiba $S$ mengeluh batuk. Setelah diperiksa, ternyata jahitan bekas operasi sobek, sehingga langsung dilarikan ke Instalasi Gawat Darurat (IGD) rumah sakit $X$. karena kondisinya cukup parah, dokter jaga di IGD langsung merujuk ke rumah sakit $\mathrm{Y}$ untuk mendapatkan perawatan intensif. Alasan rumah sakit $X$ merujuk pasien karena pihak rumah sakit tidak sanggup melakukan tindakan medis karena kondisi pasien cukup mengkhawatirkan

\section{Rumusan Masalah}

Berdasarkan latar belakang yang telah diuraikan maka diambil satu rumusan masalah mengenai bentuk tanggung gugat rumah sakit atas kesalahan diagnosa yang dilakukan oleh dokter ditinjau dari 
UU No. 44 Th. 2009 dan UU No. 29 Th. 2004

\section{Metode Penelitian}

Tipe penelitian ini menggunakan tipe penelitian normatif. Penelitian hukum normatif menurut Peter Mahmud Marzuki yaitu "Suatu proses untuk menemukan suatu aturan hukum, prinsip-prinsip hukum, maupun doktrin-doktrin hukum guna menjawab isu hukum yang dihadapi". Pendekatan yang digunakan yaitu statute approach dan conceptual approach. (Marzuki, 2010)

\section{Pembahasan}

Hubungan

hukum

(rechtsbetrekkingen) menurut Soeroso adalah "hubungan antara dua subyek hukum atau lebih mengenai hak dan kewajiban di satu pihak berhadapan dengan hak dan kewajiban di pihak lain". (Soeroso, 2002). Hubungan hukum menurut Peter Mahmud Marzuki adalah hubungan yang diatur oleh hukum. Hubungan antara sesama subyek hukum dapat terjadi antara seseorang dengan seorang lainnya, antara seseorang dengan suatu badan hukum, dan antara suatu badan hukum dengan badan hukum lainnya. (Marzuki, 2010)

Hubungan dokter dengan pasien ada dua, yaitu hubungan impersonal dan hubungan interpersonal. Hubungan impersonal adalah hubungan yang seimbang dimana hak dan kewajiban antara dokter dengan pasien selalu timbal balik. Hubungan interpersonal adalah hubungan yang tidak seimbang dimana dokter lebih dominan.
Hubungan hukum terjadi antara dokter dengan pasien. Pasien menurut Pasal 1 angka 10 UU No. 29 Tahun 2004 adalah "setiap orang yang melakukan konsultasi masalah kesehatannya untuk memperoleh pelayanan kesehatan yang diperlukan baik secara langsung maupun tidak langsung kepada dokter atau dokter gigi". S merasa perutnya sangat sakit, oleh E dibawa ke rumah sakit $X$ untuk berkonsultasi masalah kesehatannya untuk memperoleh pelayanan kesehatan secara langsung kepada dokter, sehingga $S$ memenuhi syarat sebagai pasien.

Dokter menurut Pasal 1 angka 2 UU No. 29 Tahun 2004 adalah "dokter, dokter spesialis, dokter gigi, dan dokter gigi spesialis lulusan pendidikan kedokteran atau kedokteran gigi baik di dalam maupun di luar negeri yang diakui oleh Pemerintah Republik Indonesia sesuai dengan peraturan perundangundangan". Dokter harus lulus pendidikan kedokteran, dokter yang menjalankan praktik kedokteran harus memiliki surat izin praktik sebagaimana Pasal 1 angka 7 UU No. 29 Tahun 2004, tercatat dalam surat tanda registrasi dokter sebagaimana Pasal 1 angka 8 UU No. 29 Tahun 2004.

Ketika E memutuskan S dibawa ke rumah sakit $X$ dan mendapatkan penanganan medis oleh dua dokter spesialis obstetri dan ginekologi, berarti pada saat itu juga terjadi suatu hubungan hukum antara $S$ dengan persetujuan $\mathrm{E}$ dengan dua dokter yang menangani atau melakukan tindakan kedokteran.

Di rumah sakit $X, S$ ditangani oleh dua orang dokter spesialis, 
yakni spesialis obstetri dan ginekologi, memiliki izin praktik dan tercatat dalam surat tanda registrasi dokter, sehingga dua orang dokter tersebut termasuk dokter spesialis, yang berarti telah memenuhi persyaratan sebagai pihak yang melakukan hubungan hukum dengan pasien, yaitu sebagai dokter.

Hubungan hukum antara dokter dengan pasien didasarkan atas persetujuan tindakan kedokteran, sebagaimana Pasal 45 ayat (1) UU No. 29 Tahun 2004, yang menentukan bahwa "setiap tindakan kedokteran atau kedokteran gigi yang akan dilakukan oleh dokter atau dokter gigi terhadap pasien harus mendapat persetujuan".

Hubungan hukum antara dokter dengan pasien didasarkan atas persetujuan tindakan kedokteran, sebagaimana Pasal 45 ayat (1) UU No. 29 Tahun 2004 Jo. Permenkes No. 290/ Menkes/ Per/ III/ 2008. Persetujuan tindakan medis menurut Pasal 1 angka 1 Permenkes No. 290/ Menkes/ Per/ III/ 2008 adalah "persetujuan yang diberikan oleh pasien atau keluarga terdekat setelah mendapat penjelasan secara lengkap mengenai tindakan kedokteran atau kedokteran gigi yang akan dilakukan terhadap pasien". Tindakan kedokteran menurut Pasal 1 angka 3 Permenkes No. 290/ Menkes/ Per/ III/ 2008 adalah "suatu tindakan medis berupa preventif, diagnostik, terapeutik atau rehabilitatif yang dilakukan oleh dokter atau dokter gigi terhadap pasien". Diagnostik atau terapeutik maksudnya adalah "pelayanan medis atau penyembuhan" (Komalawati, 1999). Informed consent adalah "suatu persetujuan pasien untuk menerima upaya medis yang akan dilakukan terhadapnya. Hal ini dilakukan setelah ia mendapat informasi dari dokter mengenai upaya medis dan segala resiko yang mungkin terjadi" (Nasution, 2013). Ketika S oleh E dibawa ke rumah sakit $X$ dan diperiksa oleh dua orang dokter spesialis obstetri dan ginekologi, berarti telah terjadi kesepakatan antara E untuk dan atas nama $S$ yang dalam keadaan sakit parah dengan dokter yang menanganinya. Adanya kesepakatan tindakan kedokteran tersebut, menimbulkan suatu kewajiban secara timbal balik yang dikenal dengan prestasi.

Pasien mempunyai hak untuk menentukan nasibnya sendiri dalam kaitannya dengan persetujuan dari pasien. Hak untuk menentukan nasib sendiri seperti yang telah dikemukakan oleh Hermien Hadiati Koeswadji adalah:

Hak untuk menentukan nasib sendiri ini juga disebut sebagai the right to self-determination. Hak untuk menentukan nasib sendiri lebih dekat artinya dengan yang dimaksudkan hak pribadi (personal right) yaitu hak atas keamanan pribadi yang menyangkut mengenai hidup, bagian tubuh, kesehatan, kehormatan, serta hak atas kebebasan pribadi (Koeswadji, 1998)

Hal ini menunjukkan bahwa di dalam hubungan antara dokter deenngan pasi, ketika dokter telah memberikan informasi dari hasil pemeriksaan kepada pasien, pasien mempunyai hak untuk memberikan atau menolak memberikan 
persetujuan. Persetujuan merupakan suatu hal yang mutlak. Namun, hak menentukan nasib sendiri tidak dapat terwujud secara optimal apabila tidak disertai dengan hak atas informasi. Karena keputusan mengenai penentuan nasibnya sendiri itu dapat diberikan apabila dalam pengambilan keputusan tersebut tidak memperoleh informasi yang lengkap tentang segala kemungkinan yang terjadi di dalam keputusan persetujuan tindakan medis. Seperti yang telah dikemukakan oleh Veronica Komalawati sebagai berikut:

Penjelasan dalam pemberian informasi oleh dokter lebih penting daripada penandatanganan persetujuan secara tertulis. Hal ini disebabkan, karena seseorang tidak akan menyetujui sesuatu yang tidak diketahui terlebih dahulu, dan secara yuridis persetujuan tanpa informasi adalah tidak sah. Lagipula, kenyataan menunjukkan bahwa di dalam proses terjadinya suatu hubungan hukum ditentukan adanya informasi secara timbal balik sehingga terjadi komunikasi antara para pihak dalam pencapaian kesepakatan. (Komalawati, 1999)

Persetujuan tindakan medis, baik secara tertulis maupun tidak tertulis pasien atau keluarganya yang memberikan persetujuan bukan berarti bahwa menyetujui apa yang dilakukan oleh dokter terhadap pasien, yang diberikan tersebut sifatnya hanyalah bersifat penegasan saja. Hal ini sesuai dengan yang dikemukakan oleh Veronica Komalawati sebagai berikut:
"Penandatangan informed consent secara tertulis yang dilakukan oleh pasien sebenarnya dimaksudkan sebagai penegasan atau pengukuhan dari persetujuan yang sudah diberikan setelah dokter memberikan penjelasan mengenai tindakan medik yang akan dilakukannya". (Komalawati, 1999) Karena sifatnya hanya pengukuhan atau penegasan, maka dokter dalam menjalankan profesinya tidak terbebas dari segala bentuk tanggung jawab atas sesuatu yang terjadi terhadap pasien. Tindakan medis yang ditentukan oleh dokter harus dapat dipertanggungjawabkan sesuai dengan standar profesinya. Berdasarkan hasil diagnosa dua dokter spesialis obstetri dan ginekologi, $\mathrm{S}$ mengidap sakit kista dan disarankan untuk operasi, E yang merupakan anak kandung $S$ menyetujui untuk dilakukan tindakan kedokteran berupa operasi, yang berarti bahwa hak pasien untuk menentukan nasib sendiri berupa menyetujui tindakan operasi telah diberikan oleh pasien atau keluarganya.

Hubungan antara dokter dengan pasien melahirkan dua aspek hukum, yaitu "inspanning verbintenis dan resultaat verbintenis". (Hanafiah \& Amir, 2013). Menurut Hermien Hadiati Koeswadji mengartikan inspanning verbintenis sebagai:

Hubungan hukum antara dua subyek hukum (dokter dan pasien) dan melahirkan hak dan kewajiban bagi yang bersangkutan. Hubungan hukum ini tidak menjanjikan sesuatu yang pasti, karena objek dari hubungan hukum itu 
berupa upaya maksimal yang dilakukan secar cermat dan hatihati oleh dokter berdasarkan ilmu pengetahuan dan pengalamannya untuk menyembuhkan (Koeswadji, 2002) pasien.

Bentuk prestasi dokter dalam menjalankan profesinya berupa upaya penyembuhan. Sedangkan mengenai resultaat verbintenis, yaitu hubungan hukum yang menjanjikan suatu yang pasti" (Hanafiah \& Amir, 2013). Mengenai upaya penyembuhan maupun hubungan hukum yang menjanjikan suatu yang telah pasti jika dikaitkan dengan kemampuan pasien yang terbatas dalam pembuktian, maka pihak yang diwajibkan untuk membuktikan adanya inspanning verbintenis dan resultaat verbintenis adalah tenaga kesehatan atau dokter yang bersangkutan. Dua dokter spesialis, yakni spesialis obstetri dan ginekologi yang melakukan tindakan kedokteran berupaya menyembuhkan penyakit kista yang diderita oleh pasien $\mathrm{S}$ dengan cara mengoperasi.

Dokter dalam menjalankan profesinya memperoleh perlindungan hukum sebagai haknya sesuai Pasal 50 UU No. 29 Tahun 2004 bahwa:

Dokter atau dokter gigi dalam melaksanakan praktik kedokteran mempunyai hak:

a. Memperoleh perlindungan hukum sepanjang melaksanakan tugas sesuai dengan standar profesi dan standar prosedur operasional;

b. Memberikan pelayanan medis menurut standar profesi dan standar prosedur operasional;

c. Memperoleh informasi yang lengkap dan jujur dari pasien atau keluarganya; dan

d. Menerima imbalan jasa.

Mengenai standar profesi dijelaskan lebih lanjut oleh penjelasan Pasal 50 UU No. 29 Tahun 2004 yang menentukan bahwa: "yang dimaksud dengan "standar profesi" adalah batasan kemampuan minimal yang harus dikuasai oleh seorang individu untuk dapat melakukan kegiatan profesionalnya pada masyarakat secara mandiri yang dibuat oleh organisasi profesi".

Veronica

Komalawati mengartikan standar profesi sebagai pedoman yang harus dipergunakan sebagai petunjuk dalam menjalankan profesi yang baik. Berkenaan dengan pelayanan medik, maka pedoman yang digunakannya adalah standar pelayanan medik yang lebih dititikberatkan pada proses untuk tindakan medik sehingga disebut pula sebagai standar proses sebagaimana telah disusun oleh Ikatan Dokter Indonesia, dengan maksud agar dapat digunakan sebagai pedoman secara nasional. (Komalawati, 1999)

Menurut Leenen yang dikutip dari Fred Ameln, bahwa suatu tindakan medik seorang dokter sesuai dengan standar profesi jika dilakukan secara teliti sesuai dengan ukuran medik, sebagai seorang dokter yang memiliki kemampuan rata-rata dibandingkan dengan dokter dari kategori keahlian medik yang sama dengan sarana upaya yang memenuhi perbandingan wajar 
(proportional) disbanding dengan tujuan konkret tindakan medik tersebut (Ameln, 1991).

Menurut Taylor, yang dikutip oleh J. Guwandi mengatakan bahwa seorang dokter atau ahli bedah yang memberikan pelayanan pengobatan profesional harus memenuhi syaratsyarat ia harus memiliki tingkat pengetahuan profesional, keterampilan dan kemampuan seperti orang setingkat kedudukan dengannya; harus bertindak hati-hati dan teliti dalam penerapan pengetahuannya dan kepandaiannya terhadap pasien; harus mempertimbangkan sebaik-baiknya dalam mengobati dan merawat pasiennya. (Guwandi, 2009)

Dua dokter spesialis obstetri dan ginekologi merupakan dokter ahli yang dalam memberikan pelayanan pengobatan profesional harus memenuhi syarat-syarat diantaranya memiliki tingkat pengetahuan professional, keterampilan dan kemampuan seperti orang setingkat kedudukan dengannya, harus bertindak dengan hati-hati dan teliti dalam penerapan pengetahuan dan kepandaiannya terhadap pasien, harus mempertimbangkan sebaik-baiknya dalam mengobati dan merawat pasiennya. Dua dokter spesialis obstetri dan ginekologi tersebut mendiagnosa S menderita sakit kista, namun kenyataannya pada saat dilakukan operasi, penyakit yang diderita oleh $S$ adalah penyempitan saluran kencing, sehingga perlu dilakukan perluasan operasi dari kista ke saluran kencing. Tindakan kedua dokter ahli tersebut ketika mendiagnosa pasien dapat dikatakan tidak memiliki tingkat pengetahuan profesional, tidak memiliki keterampilan dan kemampuan seperti orang yang setingkat kedudukan dengannya; tidak bertindak dengan hati-hati dan teliti dalam penerapan pengetahuannya dan kepandaiannya terhadap pasien; tidak mempertimbangkan sebaik-baiknya dalam mengobati dan merawat pasiennya.

Menurut Fred Ameln, ada dua macam dokter yang bekerja di rumah sakit. Yaitu:

Dokter yang melakukan kegiatan di rumah sakit yang bersangkutan bisa sebagai pekerja penuh dan mendapat gaji. Dokter begini disebut dokter "in", dokter purrnawaktu (full time). Dalam hal ini, rumah sakit bertanggungjawab penuh atas semua tindakan dokter "in" ini. Sebaliknya, terdapat juga dokter "out", dokter tamu, yang berarti bukan pegawai rumah sakit tersebut. Untuk dokter "out" ini, tanggung jawab bukan pada rumah sakit yang bersangkutan tapi dokter "out" sendiri. (Ameln, 1991)

Sehubungan dengan tanggung jawab dokter dalam menjalankan profesinya, Pasal 66 UU No. 29 Tahun 2004 menentukan bahwa "setiap orang yang mengetahui atau kepentingannya dirugikan atas tindakan dokter dalam menjalankan praktik kedokteran dapat mengadukan secara tertulis kepada Ketua Majelis Kehormatan Disiplin Kedokteran Indonesia". Berdasarkan Pasal 66 ayat (2) pengaduan sekurang-kurangnya harus memuat: a) Identitas pengadu; b) Nama dan alamat tempat praktik dokter dan 
waktu tindakan dilakukan; c) Alasan pengaduan.

Selain itu pengaduan tersebut tidak menghilangkan hak setiap orang untuk melaporkan adanya dugaan tindak pidana kepada pihak yang berwenang dan/atau menggugat kerugian perdata ke pengadilan. E anak kandung $\mathrm{S}$ yang merasa dirugikan akibat kurang hatihatinya dua dokter spesialis obstetri dan ginekologi dapat mengadukan kedua dokter ahli tersebut kepada Ketua Majelis Kehormatan Disiplin Kedokteran Indonesia dan menggugat ganti kerugian karena menjalankan profesinya tidak sesuai dengan standar profesi sebagaimana Pasal 50 huruf b UU No. 29 Tahun 2004.

Rumah sakit menurut Pasal 1 angka 1 UU No. 44 Tahun 2009 diartikan sebagai "institusi pelayanan kesehatan yang menyelenggarakan pelayanan kesehatan perorangan secara paripurna yang menyediakan pelayanan rawat inap, rawat jalan, dan gawat darurat". Rumah sakit menurut Fred Ameln dibedakan menjadi dua bagian, yaitu rumah sakit umum dan rumah sakit khusus, yang diartikan sebagai berikut:

"Pengertian Rumah Sakit

Umum, yaitu rumah sakit yang memberikan pelayanan kesehatan semua jenis penyakit dari yang bersifat dasar sampai dengan subspesialistik, sedangkan Rumah Sakit Khusus hanya menyelenggarakan pelayanan kesehatan berdasarkan jenis penyakit tertentu atau disiplin tertentu". (Ameln, 1991)

Rumah sakit dapat diselenggarakan oleh pemerintah maupun swasta sebagaimana Pasal 7 ayat (2) UU No. 44 Tahun 2009. Rumah sakit yang diselenggarakan oleh Pemerintah dan Pemerintah Daerah harus berbentuk Unit Pelaksana Teknis dari Instansi yang bertugas di bidang kesehatan, Instansi tertentu, atau Lembaga Teknis Daerah dengan pengelolaan Badan Layanan Umum atau Badan Layanan Umum Daerah sesuai dengan ketentuan Pasal 7 ayat (3) UU No. 44 Tahun 2009. Sedangkan, Rumah Sakit milik swasta harus berbentuk badan hukum yang kegiatan usahanya hanya bergerak di bidang perumahsakitan sebagaimana Pasal 7 ayat (4) UU No. 44 Tahun 2009. Rumah Sakit X termasuk rumah sakit umum milik Pemerintah Daerah, yang memberikan pelayanan kesehatan semua jenis penyakit dari yang bersifat dasar sampai dengan subspesialistik.

Rumah sakit sebagai institusi pelayanan kesehatan, mempunyai tugas memberikan pelayanan kesehatan perorangan secara paripurna, dalam menjalankan kegiatan pelayanan kesehatan dilaksanakan oleh tenaga kesehatan untuk memelihara dan meningkatkan kesehatan, mencegah dan menyembuhkan penyakit, dan memulihkan kesehatan. Rumah sakit $X$ dalam memberikan pelayanan kesehatan dilaksanakan oleh tenaga kesehatan sebagai tenaga medis, diantara tenaga medis tersebut adalah dua dokter spesialis obstetri dan ginekologi yang menangani pasien $\mathrm{S}$.

Salah satu hak pasien adalah memperoleh layanan yang efektif dan efisien sehingga pasien 
terhindar dari kerugian fisik dan materi. Terhindar dari kerugian fisik dan materi, yang berarti jika pasien menderita kerugian berhak untuk menggugat atau mendapatkan penggantian kerugian, sebagaimana Pasal 46 UU No. 44 Tahun 2009 yang menentukan bahwa "Rumah sakit bertanggungjawab secara hukum terhadap semua kerugian yang ditimbulkan atas kelalaian yang dilakukan oleh tenaga kesehatan di Rumah Sakit". Pasien yang menderita kerugian berhak untuk menggugat ganti rugi berdasarkan Pasal 58 ayat (1) UU No. 36 Tahun 2009 yang menentukan "setiap orang berhak menuntut ganti rugi terhadap seseorang, tenaga kesehatan, dan/atau penyelenggara kesehatan yang menimbulkan kerugian akibat kesalahan atau kelalaian dalam pelayanan kesehatan yang diterimanya". Hak pasien untuk menggugat ganti rugi, UU No. 44 Tahun 2009 tidak mengaturnya, sehingga digunakan aturan yang bersifat umum, sebagaimana gugatan ganti rugi dalam KUH Perdata.

Gugatan ganti rugi dapat terjadi karena adanya ingkar janji atau wanprestasi dan dapat pula karena adanya perbuatan melanggar hukum (onrechtmatige daad). Gugatan ganti rugi atas dasar wanprestasi terjadi karena adanya hubungan hukum antara dokter dan pasien yang didasarkan atas informed consent, dimana dokter dalam menjalankan profesinya dikatakan wanprestasi apabila:

1. tidak melakukan apa yang disanggupi akan dilakukannya;

2. melaksanakan apa yang dijanjikannya tetapi tidak

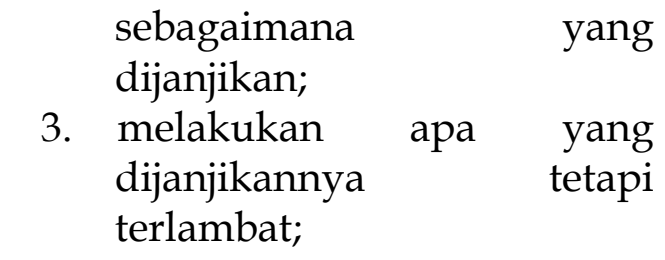

4. melakukan sesuatu yang menurut perjanjian tidak boleh dilakukannya. (Subekti, 2005)

Kedua dokter spesialis obstetri dan ginekologi tersebut telah melaksanakan prestasinya berupa tindakan operasi penyempitan saluran kencing, namun tidak sesuai dengan apa yang telah diperjanjikan sebelumnya di dalam informed consent, bahwa dokter akan melaksanakan tindakan operasi kista. Dokter dalam menjalankan profesinya tidak hati-hati dan teliti atau tidak merujuk pada dokter yang lebih ahli ketika tidak mampu mengambil tindakan. Tindakan dokter yang demikian ini dapat dikatakan telah melakukan sesuatu yang menurut perjanjian tidak boleh dilakukannya, sehingga dapat dikatakan telah ingkar janji atau wanprestasi.

Pasien yang merasa dirugikan dapat juga menggugat dengan alasan perbuatan melanggar hukum sesuai dengan pasal $1365 \mathrm{KUH}$ Perdata yang menentukan bahwa "tiap perbuatan yang melanggar hukum dan membawa kerugian kepada orang lain, mewajibkan orang yang menimbulkan kerugian itu karena kesalahannya untuk menggantikan kerugian tersebut". Ada 4 syarat yang harus dipenuhi untuk menuntut kerugian adanya perbuatan melanggar hukum, yaitu:

1. Pasien harus mengalami suatu kerugian; 
2. Ada kesalahan atau kelalaian (disamping perseorangan, rumah sakit juga bisa bertanggung jawab atas kesalahan atau kelalaian pegawainya);

3. Ada hubungan kausal antara kerugian dan kesalahan;

4. Perbuatan itu melanggar hukum. (Utomo \& Safi'i, 2019)

Kedua dokter spesialis obstetri dan ginekologi rumah sakit $X$ yang menangani pasien $S$ dikatakan telah melakukan perbuatan melanggar hukum. Dikatakan demikian karena kedua dokter spesialis obstetri dan ginekologi tersebut dalam menjalankan profesinya tidak hatihati dan teliti atau tidak merujuk pada dokter yang lebih ahli ketika tidak mampu mendiagnosa penyakit pasien.

Tindakan kedua dokter spesialis obstetri dan ginekologi tersebut yang karena kurang hatihati dan teliti mengakibatkan pasien menderita kerugian, yang berarti menjalankan profesinya tidak sesuai dengan standar profesinya, kepadanya dapat dikatakan telah melakukan perbuatan melanggar pasal 50 huruf b UU No. 29 Tahun 2004. Melanggar Undang-Undang berarti melanggar hukum sebagaimana ketentuan pasal 1365 KUH Perdata.

Unsur kesalahan tampak sebagaimana dikemukakan diatas bahwa kedua dokter spesialis obstetri dan ginekologi tersebut pada awalnya telah mendiagnosa pasien $\mathrm{S}$ mengidap penyakit kista, namun kenyataannya pada saat dilakukan operasi penyakit yang diderita oleh pasien $S$ adalah penyempitan saluran kencing.

Unsur kerugian yang dialami pasien $S$ merupakan kerugian immateriil. Dikatakan demikian karena pasien $S$ sangat menderita akibat sakit di bagian perutnya berupa jahitan bekas operasi yang sobek.

Hubungan kausal tampak dari tindakan medis yang dilakukan oleh kedua dokter spesialis obstetri dan ginekologi tersebut sebagai perbuatan melanggar hukum dengan penderitaan yang dialami pasien S. Dengan terpenuhinya unsur-unsur dari pasal 1365 KUH Perdata maka tindakan medis yang dilakukan oleh kedua dokter spesialis obstetri dan ginekologi tersebut dapat digugat ganti rugi oleh pasien $S$.

Memperhatikan uraian sebagaimana tersebut diatas dapat dijelaskan bahwa tindakan dua dokter spesialis obstetri dan ginekologi dalam menjalankan profesinya telah melanggar hak pasien, dapat digugat ganti rugi atas dasar wanprestasi sekaligus perbuatan melanggar hukum. Gugatan yang demikian diperkenankan sesuai dengan yang dikemukakan oleh Soetojo Prawirohamidjojo dan Marthalena Pohan, bahwa "suatu wanprestasi dapat sekaligus menimbulkan perbuatan yang onrechmatige daad , asalkan faktanya itu merupakan wanprestasi dan faktanya itu sendiri terjadi di luar kewajiban yang diharuskan oleh undang-undang". (Prawirohamidjojo \& Pohan, 1979) Tanggung gugat (liability/aansprakelijkheid) merupakan 
"bentuk spesifik dari tanggung jawab. Pengertian tanggung gugat merujuk kepada posisi seseorang atau badan hukum yang dipandang harus membayar suatu benuk kompensasi atau ganti rugi setelah adanya peristiwa hukum". (Utomo, 2017). Mengenai tanggung gugat Moegni Djojodirdjo memberikan penjelasan bahwa:

"adanya tanggung gugat pada seorang pelaku perbuatan melanggar hukum, maka si pelaku harus bertanggung jawab atas perbuatannya dan karena pertanggungan jawab tersebut si pelaku tersebut harus mempertanggungjawabkan perbuatannya dalam gugatan yang diajukan di hadapan pengadilan oleh penderita terhadap si pelaku". (Djojodirdjo, 1992)

Memperhatikan pengertian tanggung gugat yang disampaikan oleh Moegni Djojodirdjo di atas dapat dijelaskan bahwa tanggung gugat adalah suatu keadaan wajib menanggung kerugian yang terjadi dan disengketakan. Mengenai pihak yang bertanggung gugat ini adalah pelaku yang melakukan perbuatan, yang karena perbuatannya menimbulkan kerugian pada orang lain.

Tanggung gugat timbul karena adanya suatu kesalahan, namun sebagaimana dikemukakan oleh Peter Mahmud Marzuki bahwa "kesalahan bukan merupakan unsur yang harus dipenuhi pada setiap kasus agar seseorang bertanggung gugat. Di samping itu, seseorang atau badan hukum dimungkinkan bertanggung gugat atas tindakan orang atau badan hukum lainnya".
(Marzuki, 2010) Tanggung gugat tersebut didasarkan atas ketentuan Pasal 1367 KUH Perdata, bahwa "setiap orang tidak hanya bertanggungjawab atas kerugian yang ditimbulkan oleh dirinya sendiri, melainkan termasuk orangorang yang berada di bawah tanggungannya". Tenaga medis dalam hal ini dokter merupakan orang-orang yang berada di bawah tanggungan rumah sakit $X$, sehingga rumah sakit $X$ bertanggung gugat atas kerugian yang diderita oleh pasien $S$.

Berdasarkan uraian dan pembahasan mengenai tanggung gugat Rumah Sakit $X$ atas kesalahan diagnosa dokter yang berujung pada sobeknya jahitan bekas operasi terhadap pasien $\mathrm{S}$ ditinjau dari UU No. 44 Tahun 2009 dan UU No. 29 Tahun 2004 dapat dijelaskan bahwa rumah sakit $X$ bertanggung gugat atas kesalahan dokter yang mendiagnosa penyakit pasien $S$, karena kedua dokter spesialis obstetri dan ginekologi tersebut merupakan dokter "in". Dokter merupakan orang-orang yang berada di bawah tanggungan rumah sakit dalam hal ini Rumah Sakit X, menurut Pasal 1367 KUH Perdata, maka Rumah Sakit $X$ harus bertanggung gugat atas kerugian yang diderita oleh $S$ sebagai pasien.

\section{Kesimpulan}

Berdasarkan uraian diatas dapat disimpulkan bahwa Rumah Sakit bertanggung gugat atas kesalahan diagnosa dokter ditinjau dari UU No. 44 Tahun 2009 tentang Rumah Sakit dan UU No. 29 Tahun 2004 tentang Praktik Kedokteran, karena: 
a. Dua dokter spesialis Obstetri dan Ginekologi, mendiagnosa pasien mengidap kista, namun saat operasi dilaksanakan, penyakit yang diderita oleh $S$ ternyata penyempitan saluran kencing, tindakan dokter tersebut tidak sesuai dengan standar profesi sebagaimana Pasal 50 huruf b UU No. 29 Tahun 2004, maka dapat dikatakan telah melakukan perbuatan melanggar hukum sebagaimana Pasal 1365 KUH Perdata, karena keseluruhan unsurnya telah terpenuhi.

b. Dua dokter spesialis obstetri dan ginekologi tersebut telah melaksanakan prestasinya berupa tindakan operasi penyempitan saluran kencing, namun tidak sesuai dengan apa yang telah diperjanjikan sebelumnya di dalam informed consent, bahwa dokter akan melaksanakan tindakan operasi kista. Tindakan dokter yang demikian ini dapat dikatakan telah melakukan sesuatu yang menurut perjanjian tidak boleh dilakukannya, sehingga dapat dikatakan telah ingkar janji atau wanprestasi.

c. Pasien berhak untuk meminta ganti rugi sebagaimana Pasal 58 ayat (1) UU No. 36 Tahun 2009.

d. Dua dokter spesialis obstetri dan ginekologi tersebut adalah orangorang yang bekerja di Rumah Sakit (dokter "in"), sehingga berdasarkan pasal 1367 KUH Perdata maka tindakan dokter tersebut mengakibatkan timbulnya tanggung gugat pada rumah sakit.

\section{Saran}

a. Hendaknya dokter terutama dokter ahli dalam mendiagnosa pasien lebih berhati-hati dan teliti sesuai dengan kemampuan sebagai dokter ahli agar terbebas dari gugatan.

b. Hendaknya pasien yang dirugikan akibat kesalahan diagnosa tersebut dapat menggugat rumah sakit sebagai penanggung jawab dokter dalam memberikan pelayanan medis.

c. Membentuk lembaga independen khusus untuk mengadili dokter yang melakukan malpraktik.

\section{Daftar Pustaka}

Ameln, F. (1991). Kapita Selekta Hukum Kedokteran. Jakarta: Grafika Jaya.

Djojodirdjo, M. (1992). Perbuatan Melawan Hukum. Jakarta: Pradnya Paramita.

Guwandi, J. (2009). Dugaan Malpraktek Medik dan Draft RPP: Perjanjian Terapeutik Antara Dokter Dan Pasien. Jakarta: Balai Penerbit Fakultas Kedokteran Universitas Indonesia.

Hanafiah, J., \& Amir, A. (2013). Etika Kedokteran dan Kesehatan. Jakarta: EGC.

Koeswadji, H. H. (2002). Beberapa Permasalahan Hukum dan Medik. Bandung: Citra Aditya Bakti.

---. (1998). Hukum Kedokteran (Studi tentang Hubungan Hukum Dalam Mana Dokter Sebagai Salah Satu Pihak). Bandung: Citra Aditya Bakti.

Komalawati, V. (1999). Peranan Informed Consent dalam Transaksi Terapeutik: Suatu Tinjauan Yuridis Persetujuan dalam Hubungan Dokter dan Pasien . Bandung: Citra Aditya Bakti. 
Marzuki, P. M. (2010). Penelitian Hukum. Jakarta: Kencana Prenada Media Group.

Nasution, B. J. (2013). Hukum Kesehatan Pertanggungjawaban Dokter. Jakarta: Rineka Cipta.

Prawirohamidjojo, S., \& Pohan, M. (1979). Onrechtmatige Daad. Surabaya: Djumali.

Soeroso. (2002). Penelitian Hukum. Jakarta: Sinar Grafika.

Subekti, R. (2005). Hukum Perjanjian. Jakarta: Intermasa.

Utomo, Hatta Isnaini Wahyu. (2017). Pelaksanaan Tugas Jabatan Notaris : Bahan Diskusi Dalam Persiapan Menghadapi Ujian Kode Etik Notaris. Surabaya: Belajar Bareng Alumni Universitas Narotama.

Utomo, Hatta Isnaini Wahyu, \& Safi'i, I. (2019). Tanggung Jawab Mantan Karyawan Notaris Sebagai Saksi Akta Terhadap Kerahasian Akta. Res Judicata , 213-226. 